ROCZNIKI TEOLOGICZNE

Tom LXVI, zeszyt $10-2019$

DOI: http://dx.doi.org/10.18290/rt.2019.66.10-8

\title{
PODMIOTOWE I RODZINNE CZYNNIKI RYZYKA UZALEŻNIENIA OD INTERNETU W GRUPIE KOBIET I MĘŻCZYZN. UJĘCIE PSYCHOPEDAGOGICZNE
}

\author{
SUBJECTIVE AND FAMILY-RELATED RISK FACTORS \\ FOR THE INTERNET ADDICTION IN THE GROUP OF FEMALES AND MALES. \\ PSYCHO-PEDAGOGICAL APPROACH
}

A b s t r a c t. Obiectives. The purpose of this article was to answer the question which of the analysed subjective and family-related variables determine the risk of Internet addiction.

Material and methoods. This article makes use of the Internet Addiction Test by K. Young, Social Competences Questionnaire (A. Matczak), INTE Emotional Intelligence Questionnaire (Anna Ciechanowicz, A. Jaworska, A. Matczak) and the Parents-Child Relationship Questionnaire by A. Roe and M. Siegelman in the Polish adaptation by W.S. Kowalski (1984). In the quantitative analysis of data obtained from these psychological tests, the statistical package SPSS + and STATISTICA were used. 322 people aged 19-31 have been examined with the use of the afore-mentioned methods.

Results and conclusions. The obtained results indicate the predictive importance of social competences determining the effectiveness of respondents' functioning in intimate situations (both in the group of females and males). The following have turned out to be determinants in the group of females: father's demanding attitude, emotional intelligence and social competences determining the effectiveness of functioning in intimate situations and those requiring assertiveness. In the group of males, five prediction factors have been revealed, including: mother's

Dr Karolina Komsta-Tokarzewska - Katedra Psychopedagogiki Rodziny, Instytut Nauk o Rodzinie i Pracy Socjalnej Katolickiego Uniwersytetu Lubelskiego Jana Pawła II, adres do korespondencji: Al. Racławickie 14, 20-950 Lublin; e-mail: karolina.komsta@kul.pl 
protecting and loving attitude, father's liberal attitude and social competences determining the effectiveness of functioning in situations of social exposure and intimacy.

Key words: Internet addiction; risk factors; parental attitudes; emotional intelligence; social competences.

\section{UZALEŻNIENIE OD INTERNETU - EKSPLIKACJA POJĘCIA}

Uzależnienie od internetu (Internet Addiction) ${ }^{1}$ określane jest w literaturze przedmiotu jako: patologiczne używanie Internetu (Pathological Internet Use) ${ }^{2}$, nadmierne korzystanie z Internetu oraz problematyczne używanie Internetu (Problematic Internet Use) ${ }^{3}$, zespół uzależnienia od internetu (Jakubik) ${ }^{4}$.

Aktualnie obowiązujące klasyfikacje chorób i zaburzeń psychicznych DSM-V i ICD-10 nie definiują uzależnień technologicznych - w tym uzależnienia od Internetu - jako odrębnej kategorii. W diagnozie ryzyka uzależnienia od internetu wykorzystuje się wskazówki diagnostyczne oparte na kryteriach uzależnień od substancji chemicznych, uzależnienia od hazardu oraz innych zaburzeń nawyków i popędów. Wśród badaczy obserwuje się brak wspólnego podejścia zarówno do objawów, jak i typologii analizowanego zjawiska, oraz do poszukiwania granic między „normą” a patologią zachowań nałogowych. Przegląd literatury przedmiotu pozwala stwierdzić brak zgody badaczy co do definicji i natury zjawiska uzależnienia od internetu. Badacze o inklinacjach klinicznych zwracają uwagę na kryteria jakościowe i ilościowe klasyfikacji uzależniony-nieuzależniony, dlatego też w większym stopniu podkreślają jego kliniczne aspekty i charakteryzują je w sposób kategorialny (Griffiths ${ }^{5}$, Shapira ${ }^{6}$, Widyanto ${ }^{7}$ ). Badacze zorientowani

${ }^{1}$ K.S. Young, Internet Addiction: The Emergence of a New Clinical Disorder, „CyberPsychology \& Behavior" 1(1998), nr 3, s. 238; A. AugustyneK, Psychologiczne aspekty korzystania z Internetu, w: Formowanie się społeczności informacyjnej, red. L. Haber, Kraków: Graf 2003, s. 78.

${ }^{2}$ R.A. Davis, A Cognitive-Behavioral Model of Pathological Internet Use, „Computers in Human Behavior" 17(2001), nr 2, s. 189.

K.W. Beard, E.M. Wolf, Modification in The Proposed Diagnostic Criteria for Internet Addiction, „Cyberpsychology \& Behavior” 4(2001), nr 3, s. 381.

4 A. JAKUBiK, Zespół uzależnienia od Internetu, „Studia Psychologica” 2002, nr 3, s. 135.

5 M.D. Griffiths, A. BARnes, Internet Gambling: An Online Empirical Study among Student Gamblers, „International Journal of Mental Health and Addiction” 2008, nr 2, s. 198.

${ }^{6}$ N.A. Shapira, M.C. Lessig, T.D. Goldsmith, S.T. Szabo, M. Lazoritz, M.S. Gold, D.J. Stein, Problematic Internet Use: Proposed Classification and Diagnostic Criteria, „Depression and Anxiety” 17(2003), nr 4, s. 211.

7 L. Widyanto, M.D. Griffiths, Internet addiction: Does it really exist?, w: Psychology and the Internet: Intrapersonal, Interpersonal and Transpersonal Applications, red. J. Gackenbach, New York: Akademic Press 2007, s. 152. 
społecznie, interdyscyplinarnie podkreślają dysfunkcjonalny charakter tego syndromu (K. Young, Potenza ${ }^{8}$ ). W tej perspektywie uzależnienie od internetu czy patologiczne, nadmierne korzystanie z internetu można umieścić na kontinuum zaburzeń związanych z utratą kontroli nad czasem spędzonym online. Prezentowane w artykule badania oparto na drugim z prezentowanych podejść. Głównym powodem wyboru tego ujęcia był brak jasnych kryteriów dystynktywnych dla nowej jednostki zaburzeń, jaką stanowią uzależnienia technologiczne (w tym uzależnienie od Internetu) w ramach Klasyfikacji DSM-V ${ }^{9}$.

\section{CZYNNIKI RYZYKA W UZALEŻNIENIU OD INTERNETU}

Problematyka czynników związanych z powstawaniem zachowań problemowych w sieci jest obecnie analizowana w kontekście ich polietiologiczności. $\mathrm{Z}$ uwagi na złożoność omawianego zjawiska w niniejszym artykule oparto się na kategoryzacji uwzględniającej istotne znaczenie czynników podmiotowych i rodzinnych w powstawaniu, rozwoju i podtrzymywaniu internetowej aktywności o charakterze nałogowym.

Do puli zmiennych podmiotowych charakterystycznych dla rozwoju zjawiska uzależnienia od internetu włącza się coraz częściej te o charakterze kompetencyjnym, w tym inteligencję emocjonalną i kompetencje społeczne ${ }^{10}$.

Prowadzone na świecie badania dowodzą, że ryzykowne używanie internetu wiąże się z takimi cechami użytkowników, jak wrażliwość na społeczne odrzucenie (związana z niskimi wynikami w skali ekspozycji społecznej KKS), trudności z otwartą komunikacją interpersonalną (niskie wyniki w skali asertywności KKS) oraz niski poziom inteligencji emocjonalnej. O roli obu konstruktów - kompetencji społecznych i inteligencji emocjonalnej - jako predyktora uzależnienia od internetu można wnioskować pośrednio, na postawie badań, jakie przeprowadzili tajwańscy naukowcy L.S. Whang, S. Lee

${ }^{8}$ M.N. Potenza, Commentary on: Are we overpathologizing everyday life? A tenable blueprint for behavioral addiction research: defining and classifing non-substance or behavioral addictions, „Journal of Behavioral Addictions” 2015, nr 4, s. 140.

9 Tamże, s. 217.

${ }^{10}$ Przyjęty w prowadzonych badaniach sposób rozumienia inteligencji emocjonalnej jest najbliższy koncepcji zaproponowanej przez J.D. Mayera i P. Saloveya, traktującej IE jako zbiór zdolności do przetwarzania informacji emocjonalnych i ich wykorzystywania w celach adaptacyjnych, J.D. MaYer, P. SAloveY, Emotional inteligence, „Imagination, Cognition and Personality" 9(1990), nr 3, s. 189; J.D. Mayer, P. Salovey, D. Caruso, A Further Consideration of The Issues of Emotional Intelligence, ,Psychological Inquiry” 2004 nr 15, s. 249-255). 
i G. Chang ${ }^{11}$. Poszukiwali oni związków między korzystaniem z internetu a relacjami interpersonalnymi z rówieśnikami, relacją rodzic-dziecko oraz poziomem społecznego lęku badanych. Stworzony przez nich model został oparty na teorii Harrego S. Sullivana. Teoria ta zakłada, że społeczny lęk osoby jest uzależniony od poziomu lęku obecnego w jej otoczeniu (w tym środowisku pochodzenia) we wczesnym okresie socjalizacji. Cecha ta jest więc w dużej mierze formowana na bazie relacji między rodzicem i dzieckiem, a następnie znajduje swoje odzwierciedlenie $\mathrm{w}$ funkcjonowaniu $\mathrm{z}$ rówieśnikami, decydując m.in. o poziomie zaufania czy akceptacji ze strony grupy odniesienia.

Badania prowadzone przez Bracketta, Mayera i Warnera wskazują, że osoby o wyższym poziomie kompetencji społecznych i inteligencji emocjonalnej rzadziej angażują się w zachowania, które narażają na ryzyko ich zdrowie i samopoczucie, takie jak spożywanie alkoholu i narkotyków czy zachowania dewiacyjne ${ }^{12}$. Kontrolując owe zależności, badacze ci potwierdzili, że inteligencja emocjonalna i kompetencje społeczne mogą być czynnikami chroniącymi przed podejmowaniem zachowań ryzykownych.

Przytoczone wybrane analizy sugerują, że inteligencja emocjonalna i kompetencje społeczne, zdefiniowane i zaoperacjonalizowane za pomocą skal INTE i KKS, mogą być używane do prognozowania istotnych behawioralnych konsekwencji, w tym uzależnienia od internetu.

\section{CZYNNIKI RODZINNE}

F. Streit w teorii percepcji środowiska rodzinnego oparł się na założeniu, że istnieje bezpośredni i udokumentowany empirycznie związek między zachowaniami problematycznymi osoby a dokonywaną przez nią percepcją własnego środowiska rodzinnego. Percepcja postaw rodzicielskich przez dzieci jest odmienna od tej, jaką reprezentują osoby z zewnątrz systemu rodzinnego. Warunkiem prawidłowego rozwoju osoby jest obecność korzystnych warunków wychowawczych w rodzinie. Istotnym czynnikiem jest zarówno struktura rodziny, jak i panująca w niej atmosfera wychowawcza ${ }^{13}$. S.K. Park, analizując

11 L.S. Whang, S. Lee, G. Chang, Internet Over-users' Psychological Profiles: A Behavior Sampling Analysis on Internet Addiction, „Cyberpsychology and Behavior” 6(2003), nr 2, s. 147.

12 J.D. Mayer, P. SAlovey, D. CARuso, A Further Consideration of The Issues of Emotional Intelligence, s. 249-255.

13 J.G. Tichon, M. Shapiro, The process of sharing social support in cyberspace, „Cyberpsychology \& Behavior” 6(2003), nr 2, s. 165. 
uwarunkowania rodzinne zagrożonych uzależnieniem internautów, podkreśla znaczenie postaw rodzicielskich dla powstawania uzależnień technologicznych ${ }^{14}$.

Rezultaty wielu zarówno wcześniejszych, jak i obecnie prowadzonych badań dowodzą, że postawy rodzicielskie i związane z nimi określone sposoby traktowania dzieci przez rodziców stanowią ważny czynnik kształtujący ich dorosłe zachowania $^{15}$. Unikanie dziecka czy też nadmierna na nim koncentracja sprzyja nie tylko opóźnieniu społeczno-emocjonalnej dojrzałości dzieci, lękliwości lub braku zaufania we własne możliwości, ale może przyczynić się także do inicjowania zachowań o charakterze nałogowym ${ }^{16}$.

\section{CEL BADANIA}

Celem opisanego w niniejszym artykule badania, obejmującego osoby o różnym stopniu zaangażowania w cyberprzestrzeń - począwszy od osób, u których wykorzystywanie internetu nie powoduje żadnych negatywnych konsekwencji (niski stopień ryzyka uzależnienia od internetu), a skończywszy na grupie korzystającej z sieci w sposób wysoce destruktywny (wysoki stopień ryzyka uzależnienia od internetu) - było ustalenie podmiotowych i rodzinnych czynników zachowań związanych z użytkowaniem internetu, w tym determinujących owo ryzyko.

Literatura przedmiotu i prezentowane w tym zakresie badania pozwoliły postawić następujące pytanie badawcze: Które $\mathrm{z}$ analizowanych zmiennych niezależnych są wyznacznikami ryzyka uzależnienia od internetu w badanej grupie osób?

W odniesieniu do tak postawionego pytania przyjęto, że wyznacznikami ryzyka uzależnienia od internetu są niektóre spośród badanych zmiennych podmiotowych i rodzinnych.

${ }^{14}$ S.K. PARK, J. Y. KIM, C.B. CHO, Prevalence of Internet addiction and correlations with family factors among South Korean adolescents, ,Adolescence” 172(2008), nr 43, s. 899.

15 J.Y. YEN, C.F. YEN, C.C. CHen, Family factors of internet addiction and substance use experience in Taiwanese adolescents, „Cyberpsychology \& Behavior” 10(2007), nr 3, s. 325.

${ }^{16}$ L. LeI, Y. Wu, Adolescents' paternal attachment and internet use, ,Cyberpsychology \& Behavior" 10(2007), nr 5, s. 635. 


\section{MATERIAŁ BADAWCZY I METODY}

Listę czynników opcjonalnie związanych z zachowaniami ryzykownymi w sieci ustalono na podstawie opublikowanych wcześniejszej badań własnych autorki ${ }^{17}$ oraz na podstawie przeglądu bieżącej literatury przedmiotu ${ }^{18}$.

W badaniach zastosowano dobór warstwowo-losowy. Badaniami objęto wszystkich studentów wylosowanych kierunków i uczelni na terenie miasta Lublin, którzy wyrazili zgodę na uczestnictwo w badaniach. Badania miały charakter zbiorowy.

Ponieważ dla percepcji postaw rodzicielskich przez osobę istotny wpływ ma rodzaj i częstotliwość jej kontaktów z matką i ojcem, w badaniach wzięły udział tylko te osoby, które do 12 roku życia mieszkały z obojgiem rodziców. Czynnikiem decydującym o celowości badania studentów był fakt, że właśnie osoby w tym przedziale wieku (fazie wczesnej dorosłości) stanowią ponad połowę użytkowników sieci w Polsce ${ }^{19}$. Ponadto są oni postrzegani jako grupa wysokiego ryzyka uzależnienia od internetu. Do badań właściwych włączono 322 studentów, w tym 166 kobiet i 156 mężczyzn, słuchaczy II i III roku studiów czterech największych lubelskich uczelni. Wiek badanych wahał się w granicach 19-31 lat $(M=22,21)$. Procentowy rozkład płci badanych osób ukazują dane zawarte w tabeli 4.1 .

Tabela. 4.1. Płeć badanych osób $(N=322)$

\begin{tabular}{|l|c|c|}
\hline \multicolumn{1}{|c|}{ Pleć } & $\boldsymbol{N}$ & \% \\
\hline Kobieta & 166 & 51,55 \\
\hline Mężczyzna & 156 & 48,44 \\
\hline Ogółem & 322 & 100,00 \\
\hline
\end{tabular}

Źródło: opracowanie własne na postawie badan empirycznych

W grupie badanych $(N=322) 52 \%$ stanowiły kobiety, natomiast pozostałe $48 \%$ to mężczyźni. Ukazane proporcje odzwierciedlają prawidłowości składów osobowych kierunków wyższych uczelni, gdzie głównie prowadzone były badania.

17 B.M. Parysiewicz, K. Komsta-ToKarzewsKa, M. Wyżlic, Zachowania ryzykowne. Diagnoza, profilaktyka i terapia, Lublin: WNS KUL 2015, s. 128.

18 Tamże, s. 22., A. Augustynek, Uzależnienia komputerowe. Diagnoza, rozpowszechnienie, terapia, Warszawa: Difin 2010, s. 22.

19 Tamże, s. 24. 
Na podstawie badań zebrano odpowiednie dane empiryczne, które opracowano pod względem statystycznym. Wśród osób badanych byli internauci o różnym stopniu ryzyka uzależnienia (niskim, średnim i wysokim) ${ }^{20}$.

W badaniu zostały zastosowane następujące metody pomiaru zmiennych: Test Uzależnienia od Internetu (Internet Addiction Test) K. Young, Kwestionariusz Kompetencji Społecznych (A. Matczak) ${ }^{21}$, Kwestionariusz Inteligencji Emocjonalnej INTE (Anna Ciechanowicz, A. Jaworska, A. Matczak), Kwestionariusz Stosunków Między Dziećmi i Rodzicami PCR (Parents-Child Relationship Questionnaire) autorstwa A. Roe i M. Siegelmana w polskiej adaptacji Włodzimierza S. Kowalskiego (1984) ${ }^{22}$. W analizie ilościowej danych uzyskanych na podstawie wymienionych testów psychologicznych wykorzystany został pakiet statystyczny SPSS+ oraz STATISTICA. Na podstawie regresji krokowej postępującej ustalono wyznaczniki ryzyka uzależnienia od internetu.

\section{WYNIKI}

Na podstawie kryterium objawowego uwzględnionego w Teście Uzależnienia od Internetu K. Young wyznaczono stopień zaangażowania badanych osób $\mathrm{w}$ internet $\mathrm{w}$ dekompozycji na płeć. $\mathrm{W}$ tabeli 5.1. przedstawiono wyniki badań dla zmiennej stopnia ryzyka uzależnienia od Internetu w grupie kobiet i mężczyzn.

${ }^{20}$ Grupy zostały wyróżnione na postawie Testu Uzależnienia od Internetu autorstwa K. Young.

21 A. MatczaK, Kwestionariusz Kompetencji Społecznych. Podręcznik, Warszawa: Pracownia Testów Psychologicznych Polskiego Towarzystwa Psychologicznego 2001, s. 4-16.

${ }^{22}$ Zdecydowano się na wykorzystanie narzędzia do pomiaru postaw rodzicielskich w percepcji dzieci, ponieważ niektórzy badacze są skłonni uznawać relacje dzieci o postawach swoich rodziców za bardziej wiarygodne, dokładne i wnikliwe niż własne sprawozdanie matek i ojców na ten temat (M. HelPER, Parental Evaluation of Children and Children's Self-evaluation, „Journal of Abnormal Social Psychology" 56(1958), s. 191; M. OchmaŃski, Wybrane poznawcze i środowiskowe uwarunkowania osiagnięć szkolnych dzieci rozpoczynajacych naukę, Lublin: UMCS 1995, s. 121). Ponadto w literaturze przedmiotu odnaleźć można poparte danymi empirycznymi dowody na to, że na rozwój dziecka większy wpływ mają spostrzegane a nie rzeczywiste zachowania rodziców (P. BRzozowsKI, CRPBI - Kwestionariusz do badania zachowania się rodziców w percepcji Dzieci, w: Z badań nad postawami rodzicielskimi, red. K. Pospiszyl, Lublin: UMCS 1988, s. 11). 
Tabela 5.1. Średnie wyniki uzyskane w Teście Uzależnienia od Internetu

K. Young w zależności od płci $(N=322)$

\begin{tabular}{|c|c|c|c|c|c|c|}
\hline \multirow{2}{*}{ Zmienne } & \multicolumn{2}{|c|}{$\begin{array}{c}\text { Mężczyźni } \\
(\boldsymbol{N}=\mathbf{1 5 6})\end{array}$} & \multicolumn{2}{c|}{$\begin{array}{c}\text { Kobiety } \\
(\boldsymbol{N}=\mathbf{1 6 6})\end{array}$} & Test t & p \\
\cline { 2 - 5 } & M & SD & M & SD & & \\
\cline { 2 - 4 } $\begin{array}{l}\text { Wynik Testu } \\
\begin{array}{l}\text { Uzależnienia } \\
\text { od Internetu }\end{array}\end{array}$ & 69,14 & 22,53 & 57,19 & 27,21 & $-4,302$ & 0,001 \\
\hline
\end{tabular}

Adnotacja. $M$ - średnia arytmetyczna; $S D$ - odchylenie standardowe; $\mathrm{t}$ - test t-Studenta; $p$ - poziom istotności statystycznej

Źródło: opracowanie własne na postawie badan empirycznych

Średni wynik zaangażowania respondentów w internet wynosi dla mężczyzn $69,14(S D=22,53)$, zaś dla kobiet 57,19 $(S D=27,21)$. Uzyskana wartość badanej zmiennej w populacji mężczyzn jest istotnie wyższa w porównaniu z grupą kobiet $(\mathrm{t}=-4,302 ; d f=315 ; p<0,001)$. Średnie wyniki uzyskane $\mathrm{w}$ Teście Uzależnienia od Internetu K. Young w zależności od płci zamieszczono w tabeli 5.2.

Uwzględniając istniejącą między płciami istotną statystycznie różnicę w zakresie wyniku w omawianym teście, stwierdzono zasadność prowadzenia odrębnych analiz dotyczących grupy mężczyzn i kobiet.

W celu dokonania dalszej charakterystyki otrzymanych wyników w Teście Uzależnienia od Internetu K. Young, na postawie kategoryzacji wyników w przedziałach 20-49 punktów (wyniki niskie), 50-79 punktów (wyniki średnie), 80-100 punktów (wyniki wysokie), wyodrębniono 3 grupy osób badanych, różniących się stopniem ryzyka uzależnienia od internetu. Przyjęto, że wyniki niskie oznaczają niski stopień ryzyka uzależnienia; wyniki średnie oznaczają umiarkowane ryzyko uzależnienia; zaś wyniki wysokie - oznaczają wysoki poziom ryzyka uzależnienia (tabela 5.2.).

Tabela 5.2. Stopień ryzyka uzależnienia od Internetu $(N=322)$

\begin{tabular}{|c|c|c|c|l|c|c|c|c|}
\hline $\begin{array}{c}\text { Stopień } \\
\text { ryzyka } \\
\text { uzależnienia } \\
\text { od Internetu }\end{array}$ & $\begin{array}{c}\text { Wyniki testu } \\
\text { Uzależnienia } \\
\text { od Internetu } \\
\text { dla kobiet }\end{array}$ & $\boldsymbol{N}$ & $\boldsymbol{\%}$ & $\begin{array}{c}\text { Wyniki testu } \\
\text { Uzależnienia } \\
\text { od Internetu } \\
\text { dla mężczyzn }\end{array}$ & $\boldsymbol{N}$ & $\boldsymbol{\%}$ & \multicolumn{2}{|c|}{$\begin{array}{c}\text { Razem } \\
\text { (N=322) }\end{array}$} \\
\cline { 5 - 10 } $\mathrm{N}$ & $20 \leq \mathrm{M} \leq 49$ & 58 & 34,9 & $20 \leq \mathrm{M} \leq 49$ & 41 & 26,3 & 99 & $\%$ \\
\hline $\mathrm{S}$ & $50 \leq \mathrm{M} \leq 79$ & 52 & 31,3 & $50 \leq \mathrm{M} \leq 79$ & 57 & 36,5 & 109 & 30,7 \\
\hline $\mathrm{W}$ & $80 \leq \mathrm{M} \leq 100$ & 56 & 33,7 & $80 \leq \mathrm{M} \leq 100$ & 58 & 37,2 & 114 & 35,4 \\
\hline \multicolumn{2}{|c|}{ Ogółem } & 166 & 100 & & 156 & 100 & 322 & 100 \\
\hline
\end{tabular}

Adnotacja. N - niski stopień ryzyka uzależnienia od internetu; Ś - średni stopień ryzyka uzależnienia od internetu; $\mathrm{W}$ - wysoki stopień ryzyka uzależnienia od internetu - ogółem $(N=322)$ Źródło: opracowanie własne na postawie badań empirycznych 
W grupie niskiego ryzyka uzależnienia od internetu znalazło się $34,9 \%$ kobiet i $26,3 \%$ mężczyzn. Ponad $30 \%$ populacji obu płci $31,3 \%$ kobiet oraz $36,5 \%$ mężczyzn) zostało zakwalifikowanych do grupy średniego stopnia ryzyka uzależnienia od internetu, obejmującej użytkowników ponoszących największe straty związane z nadmiernym korzystaniem z tego medium. Osoby zagrożone ryzykiem uzależnienia stanowiły odpowiednio 33,7\% badanych kobiet oraz 37,2\% mężczyzn. Udział procentowy osób zagrożonych ryzykiem uzależnienia od internetu w sposób znaczny w całej populacji badanych odbiegał od rezultatów uzyskiwanych w dotychczas prowadzonych badaniach. Z badań R. Poprawy przeprowadzonych na próbie 3925 badanych w wieku od 11 do 65 roku życia wynika, że wśród młodych internautów do 24 roku życia nieco ponad $13 \%$ uzyskuje wysokie wyniki i należy do grupy ryzyka patologicznego używania internetu $^{23}$.

W prezentowanych w artykule badaniach ponad 37\% mężczyzn i ponad 33\% kobiet zostało zakwalifikowanych jako osoby o wysokim stopniu ryzyka uzależnienia, co stanowi znaczną wielokrotność danych uzyskanych w dotychczasowych analizach badawczych. Przyczyn tendencji wzrostowej można upatrywać w postępującym procesie usieciowienia gospodarstw domowych oraz instytucji użytku publicznego (w tym szkół i uniwersytetów), jak również w rosnącym dostępnie do internetu w telefonach.

\section{CZYNNIKI PREDYKCJI}

W wyniku przeprowadzonej analizy wyników uzyskano rozwiązanie, w którym predyktorami istotnymi dla ryzyka uzależnienia od internetu w grupie kobiet okazały się zmienne: postawa wymagająca ojca, wynik ogólny poziomu inteligencji emocjonalnej oraz kompetencje społeczne warunkujące efektywność funkcjonowania w sytuacjach wymagających intymności i asertywności w Kwestionariuszu Kompetencji Społecznych (tabela 5.3.).

${ }^{23}$ R. Poprawa, Problematyczne używanie internetu - symptomy i metoda diagnozy. Badania wśród dorastającej młodzieży, „Psychologia Jakości Życia” 11(2012), nr 1, s. 57-60. 
Tabela 5.3. Wyniki regresji liniowej krokowej dla zmiennej zależnej - ryzyka uzależnienia od Internetu mierzonego testem IAT K. Young (w grupie kobiet)

\begin{tabular}{|c|c|c|c|c|c|c|c|}
\hline Zmienne & $R$ & $R^{2}$ & $B$ & $S E B$ & $F$ & $\beta$ & \\
\hline D_O & 0,814 & 0,663 & $-0,120$ & 0,030 & $322,333 * * *$ & $-0,155$ & $-3,997 * * *$ \\
\hline INTE & 0,945 & 0,892 & $-0,608$ & 0,081 & $265,295^{* * *}$ & $-0,386$ & $-7,524 * * *$ \\
\hline I-KKS & 0,963 & 0,927 & $-2,667$ & 0,656 & $335,976 * * *$ & $-0,289$ & $-4,063 * * *$ \\
\hline A-KKS & 0,964 & 0,930 & $-1,456$ & 0,566 & $299,095^{* * *}$ & $-0,159$ & $-2,572 * *$ \\
\hline Wartość stała & & & 151,594 & 10,751 & & 14,101 & $14,101 * * *$ \\
\hline
\end{tabular}

$R=0,964 ; R^{2}=0,930, p=0,001 ; F=299,095 ; d f=7$

Adnotacja. $R^{2}$ - współczynnik determinacji wielokrotnej; SE-B - błąd; $\beta$-wskaźnik Beta; $B$ - współczynnik Beta, $t$ - wartość statystyki t; D_O - postawa wymagająca ojca

$* * p<0,01 ; * * * p<0,001$

Źródło: opracowanie własne na postawie badań empirycznych

Wskaźniki uwzględnione w otrzymanym modelu wyjaśniają łącznie 93\% wariancji zmiennej zależnej $\left(R^{2}=0,930\right)$, z czego największą moc predykcyjną posiada postawa wymagająca ojca $(\beta=-0,155 ; t=-3,997 ; p<0,001)$; w dalszej kolejności wynik ogólny poziomu inteligencji emocjonalnej $(\beta=-0386 ; t=-7,524 ; p<0,001)$; skala intymności w Kwestionariuszu Kompetencji Społecznych $(\beta=-0,289$; $t=-4,063 ; p<0,001)$ oraz asertywność jako wyznacznik kompetencji społecznych (Kwestionariuszu Kompetencji Społecznych) ( $\beta=-0,159 ; t=-2,572 ; p<0,01)$.

Wartości Beta wskazują, że im mniejsze nasilenie postawy wymagającej ojca i niższy poziom inteligencji emocjonalnej, intymności i asertywności, tym większe zagrożenie ryzykiem uzależnienia od internetu w grupie kobiet. Wyniki zaprezentowano w wersji graficznej na rysunku 5.1.

Rysunek 5.1. Wyznaczniki ryzyka uzależnienia od internetu w grupie kobiet

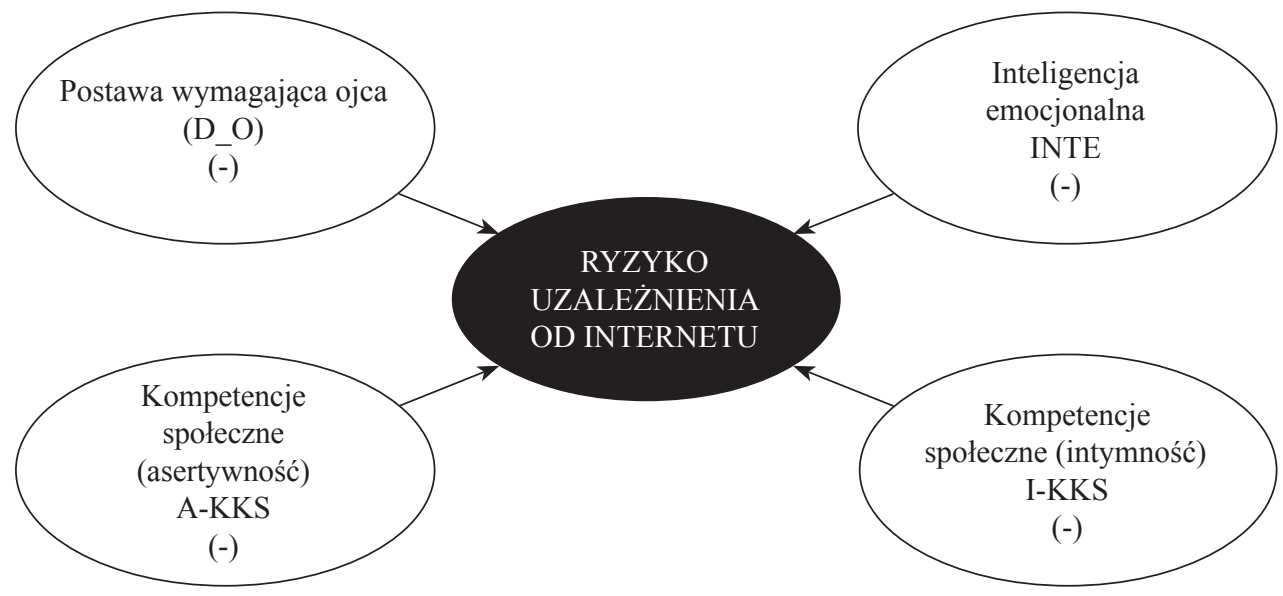


Adnotacja: KKS-I - kompetencje warunkujące efektywność funkcjonowania w sytuacjach intymnych; KKS-A - kompetencje społeczne warunkujące efektywność zachowań w sytuacjach wymagających asertywności, INTE - inteligencja emocjonalna

Źródło: opracowanie własne na postawie badań empirycznych

W badanej grupie mężczyzn rolę predykcyjną dla ryzyka uzależnienia od internetu pełni 5 czynników spośród analizowanych zmiennych (tabela 5.4.).

Tabela 5.4. Wyniki regresji liniowej krokowej dla zmiennej zależnej - ryzyka uzależnienia od Internetu mierzonego testem IAT K. Young (w grupie mężczyzn)

\begin{tabular}{|c|c|c|c|c|c|c|c|}
\hline Zmienne & $R$ & $R^{2}$ & $B$ & $S E B$ & $F$ & $\beta$ & \\
\hline L_M & 0,844 & 0,712 & $-2,371$ & 0,397 & $189,152 * * *$ & $-0,356$ & $-5.967 * * *$ \\
\hline $\mathrm{C} \_\mathrm{O}$ & 0,876 & 0,767 & 1,374 & 0,401 & $124,287^{* * *}$ & 0,134 & $3,430 * * *$ \\
\hline ES-KKS & 0,943 & 0,888 & $-2,231$ & 0,693 & $129,089 * * *$ & $-0,163$ & $-3,221 * *$ \\
\hline I-KKS & 0,938 & 0,880 & $-3,295$ & 0,606 & $135,298 * * *$ & $-0,257$ & $-5,433 * * *$ \\
\hline A_M & 0,890 & 0,920 & 1,705 & 0,492 & $94,731 * * *$ & 0,235 & $3,467 * *$ \\
\hline Wartość stała & & & 103,345 & 14,274 & & & $7,240 * * *$ \\
\hline
\end{tabular}

$R=0,890 ; R^{2}=0,92, p=0,001 ; F=94,731 ; d f=6$

Adnotacja. $R^{2}$ - współczynnik determinacji wielokrotnej; $S E-B$ - błąd; $\beta$-wskaźnik Beta; $B$ - współczynnik Beta, $t$ - wartość statystyki t; A_M - postawa ochraniająca matki; I-KKS kompetencje społeczne warunkujące efektywność funkcjonowania w sytuacjach intymnych; L_M - postawa kochająca matki; C_O - postawa liberalna ojca; ES-KKS - kompetencje warunkujące efektywność funkcjonowania w sytuacjach ekspozycji społecznej

** $p<0,01 ; * * * p<0,001$

Źródło: opracowanie własne na postawie badań empirycznych

Predyktorami istotnymi dla zjawiska ryzyka uzależnienia od internetu w grupie mężczyzn okazały się: postawa kochająca matki, postawa liberalna ojca, ekspozycja społeczna i intymność w Kwestionariuszu Kompetencji Społecznych oraz postawa ochraniająca matki. Wyjaśniają one łącznie 92\% zmienności wyników, z czego największy udział w przewidywaniu zmiennej zależnej ma postawa kochająca matki $(\beta=-0,356 ; t=-5,967 ; p<0,001)$. Pozostałe zmienne mają mniejsze znaczenie predykcyjne: postawa liberalna ojca $(\beta=-0,134 ; t=-3,430 ; p<0,001)$, ekspozycja społeczna $(\beta=-0,163 ; t=-3,221 ; p<0,01)$ i intymność $(\beta=-0,257$; $t=-5,443 ; p<0,001)$ badana Kwestionariuszem Kompetencji Społecznych oraz postawa ochraniająca matki $(\beta=0,235 ; \mathrm{t}=3,467 ; p<0,01)$.

Znak wskaźnika Beta jest podstawą do wnioskowania, że im mniejsze nasilenie postawy kochającej matki a większe nasilenie postawy liberalnej ojca i postawy ochraniającej matki oraz im mniejszy poziom intymności i ekspozycji społecznej, tym większe ryzyko ponoszenia negatywnych reperkusji wynikających 
$\mathrm{z}$ nadmiernego zaangażowania $\mathrm{w}$ internet u mężczyzn. Na rysunku 5.2. pokazano graficzną reprezentację relacji między zmiennymi.

Rysunek 5.2. Wyznaczniki ryzyka uzależnienia od internetu w grupie mężczyzn

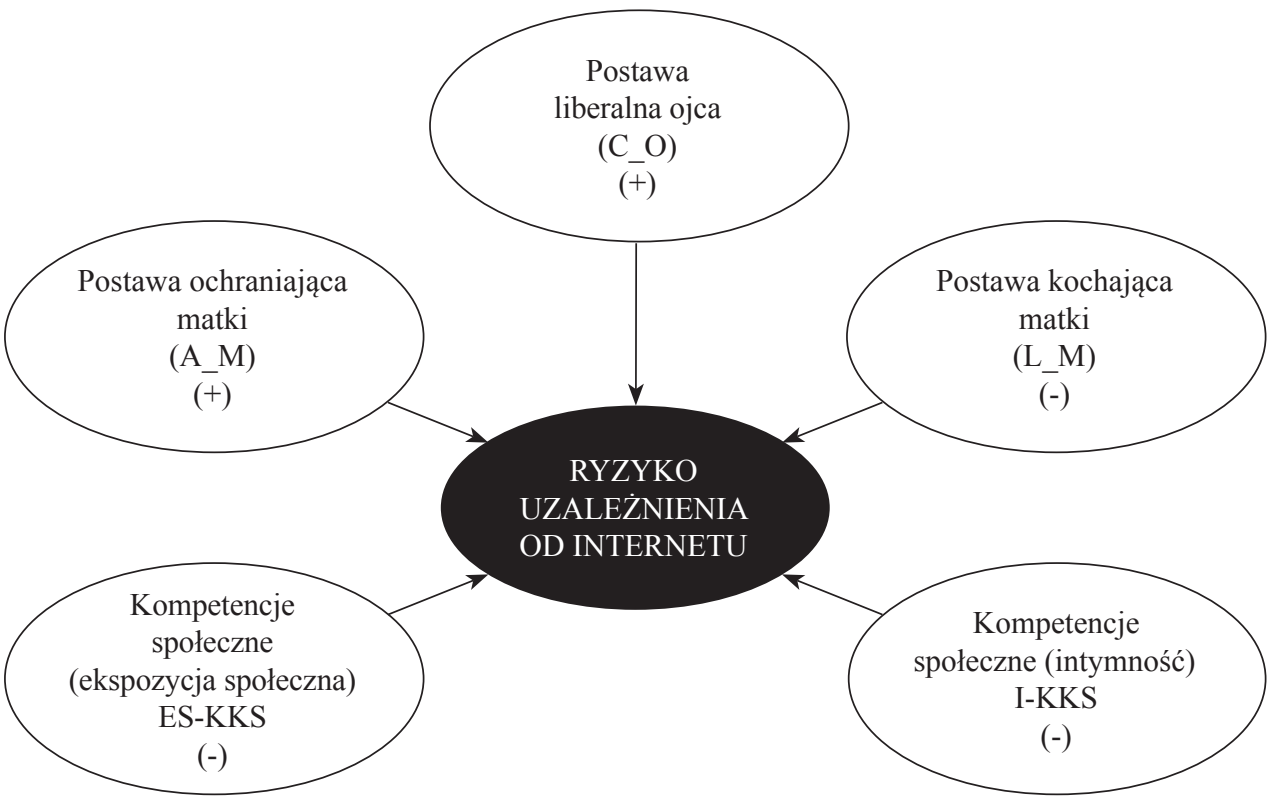

Adnotacja. A_M - postawa ochraniająca matki; I-KKS - kompetencje społeczne warunkujące efektywność funkcjonowania w sytuacjach intymnych; L_M - postawa kochająca matki; C_O - postawa liberalna ojca; ES-KKS - kompetencje społeczne warunkujące efektywność funkcjonowania w sytuacjach ekspozycji społecznej

Źródło: opracowanie własne na postawie badań empirycznych

\section{OMÓWIENIE WYNIKÓW}

Na postawie uzyskanych wyników analizy regresji stwierdzono wśród czynników wpływających na ryzyko uzależnienia od internetu obecność jednego wyznacznika zmiennej zależnej (ryzyka uzależnienia od internetu) wspólnego dla kobiet i mężczyzn, jaką stanowią kompetencje społeczne warunkujące efektywność funkcjonowania osób badanych w sytuacjach intymnych. Determinantami w grupie kobiet okazały się: postawa wymagająca ojca, inteligencja emocjonalna oraz kompetencje społeczne warunkujące efektywność funkcjonowania w sytuacjach intymnych oraz wymagających asertywności. Tak więc im silniejsza postawa 
wymagająca ojca, większa inteligencja emocjonalna oraz nasilenie kompetencji społecznych warunkujących efektywne funkcjonowanie w sytuacjach intymnych asertywnych, tym mniejsze ryzyko uzależnienia od internetu. W grupie mężczyzn ujawniono 5 predyktorów, którymi są: postawa ochraniająca i kochająca matki, postawa liberalna ojca oraz kompetencje społeczne warunkujące efektywność funkcjonowania w sytuacjach ekspozycji społecznej i intymności. Nadmierne ochranianie przez matkę i brak konsekwencji w wychowaniu przez ojca sprzyjają ryzyku uzależnienia dziecka. Postawa kochająca matki (pełna akceptacji i czułości) obniża owo ryzyko. Ponadto wyższe kompetencje społeczne warunkujące radzenie sobie w sytuacjach ekspozycji społecznej i intymności pełnią walor protekcyjny w zakresie ryzyka uzależnienia od internetu badanych mężczyzn.

\section{WNIOSKI I IMPLIKACJE PSYCHOPEDAGOGICZNE}

Analiza czynników zwiększających ryzyko uzależnienia od internetu w populacji kobiet i mężczyzn wyraźnie wskazuje, że wyjaśnienia przyczyn tych zachowań należy poszukiwać posiłkując się modelem polietiologicznym (wieloczynnikowym), uwzględniając znaczenie zarówno wyznaczników podmiotowych, jak i rodzinnych. W rozwoju internetowej zależności istotne znaczenie mają zarówno inteligencja emocjonalna i kompetencje społeczne, jak i postawy rodzicielskie rodziców osób badanych.

F. Streit w swojej teorii percepcji środowiska rodzinnego podkreśla, że brak zachowań ryzykownych występuje u tych osób, które spostrzegają swoich rodziców jako osoby obdarzające ciepłymi uczuciami i realizujące swoją miłość w granicach kochającej swobody i kochającej kontroli. Ten układ rodzicielskich cech pozwala dzieciom na zaspokojenie ich podstawowych potrzeb, przy zachowaniu zdrowej autonomii rozwoju.

W prawidłowo realizowanym procesie wychowawczym osoba buduje swoją sprawność i odpowiedzialność życiową, a tym samym rozwija swoją odporność na podejmowanie zachowań ryzykownych. Odporność ta pomaga osobie uniknąć, zminimalizować lub pokonać czynniki ryzyka, a tym samym sprawia, że w sytuacji doznawania stresu czy deprywacji potrzeb nie podejmuje ona zachowań problemowych ${ }^{24}$. Wyniki przeprowadzonych badań wskazują na postawy rodzicielskie i kontrolowane zmienne podmiotowe jako czynniki protekcji nadmiernego korzystania z sieci.

${ }^{24}$ Z. GAŚ, Rodzina a uzależnienia, Lublin: UMCS 1994, s. 50. 
Istnieją czynniki chroniące, które posiadają szerokie spektrum działania (są uniwersalne dla użytkowników internetu) oraz czynniki o selektywnym spektrum, mające ograniczone działanie na zachowania online. Należy podkreślić znaczenie bezpośredniej lub pośredniej aktywności rodziców w rozwijaniu tych czynników. Selektywne spektrum działania wykazały takie czynniki, jak: postawa kochająca rodziców oraz adekwatne wymagania wobec dzieci. Ta grupa czynników wskazuje na ochronne znaczenie środowiska rodzinnego internautów. Powyższe ustalenia są kluczowe dla planowania profilaktyki rodzinnej i społecznej osób z grup ryzyka uzależnienia od internetu.

\section{BIBLIOGRAFIA}

Augustynek A., Psychologiczne aspekty korzystania z Internetu, w: Formowanie się społeczności informacyjnej, red. L. Haber, Kraków: Test Graf 2003, s. 73-94.

Augustynek A., Uzależnienia komputerowe. Diagnoza, rozpowszechnienie, terapia, Warszawa: Difin 2010, s. 18.

Beard K.W., Wolf E.M., Modification in The Proposed Diagnostic Criteria for Internet Addiction, „Cyberpsychology \& Behavior” 4(2001), nr 3, s. 377-383.

BRzozowski P., CRPBI - Kwestionariusz do badania zachowania się rodziców w percepcji dzieci, w: Z badań nad postawami rodzicielskimi, red. K. Pospiszyl, Lublin: UMCS 1988, s. 9-20.

DAvis R.A., A Cognitive-Behavioral Model of Pathological Internet Use, „Computers in Human Behavior" 17(2001), nr 2, s. 187-195.

GAś Z., Rodzina a uzależnienia, Lublin: UMCS 1994.

Griffiths M.D., Barnes A., Internet Gambling: An Online Empirical Study among Student Gamblers, „International Journal of Mental Health and Addiction” 2008, nr 2, s. 194-204.

Helper M., Parental Evaluation of Children and Children's Self-evaluation, ,Journal of Abnormal Social Psychology" 56(1958), nr 2, s. 190-194.

JAKUBiK A., Zespół uzależnienia od Internetu, ,Studia Psychologica” 2002, nr 3, s. 135. s. 133-142.

LeI L., Wu Y., Adolescents paternal attachment and internet use, „Cyberpsychology \& Behavior” 10(2007), nr 5, s. 633-639.

Matczak A., Kwestionariusz Kompetencji Społecznych. Podręcznik, Warszawa: Pracownia Testów Psychologicznych Polskiego Towarzystwa Psychologicznego 2001.

Mayer J.D., Salovey P., Caruso D., A Further Consideration of The Issues of Emotional Intelligence, „Psychological Inquiry” 2004, nr 15, s. 249-255.

Mayer J.D., Salovey P., Emotional intelligence, „Imagination, Cognition and Personality” 9(1990), nr 3, s. 185-211.

OchMAŃSKi M., Wybrane poznawcze i środowiskowe uwarunkowania osiągnięć szkolnych dzieci rozpoczynających naukę, Lublin: UMCS 1995.

PArk S.K., Кiм J.Y., Сно C.B., Prevalence of Internet addiction and correlations with family factors among South Korean adolescents, „Adolescence” 172(2008), nr 43, s. 895-909.

Parysiewicz B.M., Komsta-Tokarzewska K., Wyżlic M., Zachowania ryzykowne. Diagnoza, profilaktyka i terapia, Lublin: WNS KUL 2015.

Poprawa R., Problematyczne używanie internetu - symptomy i metoda diagnozy. Badania wśród dorastającej młodzieży, „Psychologia Jakości Życia” 11(2012), nr 1, s. 57-60. 
Potenza M.N., Commentary on: Are we overpathologizing everyday life? A tenable blueprint for behavioral addiction research: defining and classifing non-substance or behavioral addictions, „Journal of Behavioral Addictions” 2015, nr 4, s. 139-141.

Shapira N.A., Lessig M.C., Goldsmith T.D., Szabo S.T., Lazoritz M., Gold M.S., Stein D.J., Problematic Internet Use: Proposed Classification and Diagnostic Criteria, „Depression and Anxiety" 17(2003), nr 4, s. 207-216.

Tichon J.G., ShaPIRo M., The process of sharing social support in cyberspace, „Cyberpsychology \& Behavior" 6(2003), nr 2, s. 161-170.

Whang L.S., Lee S., Chang G., Internet Over-users' Psychological Profiles: A Behavior Sampling Analysis on Internet Addiction, „Cyberpsychology \& Behavior” 6(2003), nr 2, s. 143-150.

Widyanto L., Griffiths M.D., Internet addiction: Does it really exist?, w: Psychology and the Internet: Intrapersonal, Interpersonal and Transpersonal Applications, red. J. Gackenbach, New York: Akademic Press 2007, s. 141-163.

Yen J.Y., Yen C.F., Chen C.C., Family factors of internet addiction and substance use experience in Taiwanese adolescents, „Cyberpsychology \& Behavior” 10(2007), nr 3, p. 323-329.

Young K.S., Internet Addiction: The Emergence of a New Clinical Disorder, „Cyberpsychology \& Behavior" 1(1998), nr 3, s. 237-244.

\section{PODMIOTOWE I RODZINNE CZYNNIKI RYZYKA UZALEŻNIENIA OD INTERNETU W GRUPIE KOBIET I MĘŻCZYZN. UJĘCIE PSYCHOPEDAGOGICZNE}

\section{Streszczenie}

Cel badań. Celem niniejszego artykułu było udzielenie odpowiedzi na pytanie: które z analizowanych zmiennych podmiotowych i rodzinnych są wyznacznikami ryzyka uzależnienia od internetu.

Materiał i metody. W badaniach zastosowano Test Uzależnienia od Internetu (Internet Addiction Test) K. Young, Kwestionariusz Kompetencji Społecznych (A. Matczak), Kwestionariusz Inteligencji Emocjonalnej INTE (Anna Ciechanowicz, A. Jaworska, A. Matczak), Kwestionariusz Stosunków Między Dziećmi i Rodzicami PCR (Parents-Child Relationship Questionnaire) autorstwa A. Roe i M. Siegelmana, w polskiej adaptacji Włodzimierza S. Kowalskiego (1984). W analizie ilościowej danych uzyskanych na podstawie wymienionych testów psychologicznych wykorzystany został pakiet statystyczny SPSS + oraz STATISTICA. Wskazanymi metodami przebadano 322 osoby w wieku 19-31 lat.

Wyniki i wnioski. Uzyskane wyniki badań wskazały na predykcyjne znaczenie kompetencji społecznych warunkujących efektywność funkcjonowania osób badanych w sytuacjach intymnych (zarówno w grupie kobiet, jak i w grupie mężczyzn). Determinantami w grupie kobiet okazały się: postawa wymagająca ojca, inteligencja emocjonalna oraz kompetencje społeczne warunkujące efektywność funkcjonowania w sytuacjach intymnych oraz wymagających asertywności. W grupie mężczyzn ujawniono 5 czynników predykcji, w tym: postawę ochraniającą i kochającą matki, postawę liberalną ojca oraz kompetencje społeczne warunkujące efektywność funkcjonowania w sytuacjach ekspozycji społecznej i intymności.

Słowa kluczowe: uzależnienie od internetu; czynniki ryzyka; postawy rodzicielskie; inteligencja emocjonalna; kompetencje społeczne. 